\title{
Government Marketing Public Relations Strategy in Preparing Halal Tourism in Priangan Region
}

\author{
${ }^{1}$ SUSIE PERBAWASARI, ${ }^{2}$ DIAN WARDIANA SJUCHRO, ${ }^{3}$ Y ANTI SETIANTI, \\ ${ }^{4}$ AAT RUCHIAT NUGRAHA, ${ }^{5}$ HANNY HAFIAR \\ 1,2,3,4,5Universitas Padjadjaran, Jalan Bandung-Sumedang Km.21, Jatinangor, Indonesia \\ email: ${ }^{1}$ susie.perbawasari@unpad.ac.id; ${ }^{2}$ dian.wardiana@unpad.ac.id; ${ }^{3}$ yanti.setianti@unpad.ac.id; \\ ${ }^{4}$ ruchiat@unpad.ac.id; ${ }^{5}$ hanny.hafiar@unpad.ac.id
}

\begin{abstract}
Islamic civilization has become an economic power that can influence the development of the world economy, including tourism activities. The halal tourism market trend in Indonesia is growing in line with the growing strength of the world sharia economy and the great opportunities of the world Muslim community who want comfort when traveling in a place, based on Islamic values. The purpose of this study is to find out the pull, push, and pass strategies of marketing public relations in places that have the potential of halal tourism destinations in the Priangan area. The method used in this study is qualitative with a type of descriptive study, and the collecting data technique based on observation, interviews, and focus group discussions with stakeholders related to the development of Garut and Pangandaran tourism. The results of the study show that the push strategy carried out by the government is in the form of socialization, education, and dissemination form of halal tourism policies to tourism stakeholders. The pull strategy is carried out in the formation of news on social media regarding the potential destination of halal tourism development by the tourism activist community. The last one is the pass, a strategy carried out by organizing promotional events for regional tourist destinations in collaboration with travel agents and tourism activists.
\end{abstract}

Keywords: marketing public relations, halal tourism, strategy

\section{Introduction}

The digital world is currently growing and developing faster and has the effect that all information can be received by anyone and everywhere. The shift to the digital world trends in various aspects of life are not only limited in the form of information, but digital media has become a new medium for the promotion campaign of a product or service. One form of product and service is in the form of tourism activities. Indonesian tourism through the tourism ministry is using this momentum to stir up tourism turmoil through digital media. Tourism is one of the elements of the economic movement of the country and region that can provide opportunities for improving the community's welfare if managed properly by the government and tourism industry. The importance of tourism is in accordance with the statement by (Widyastuti, 2011) which states that tourism is the main source of regional income in addition to foreign exchange from the wealth of non-renewable energy sources. The position of tourism today based on the use of information technology has become a major need and lifestyle as well as education in some millennial communities. The central government establishes tourism as the leading sector in national development so that it becomes a great opportunity for stakeholders to develop various potential natural and cultural tourism in the regions, including the concept of halal tourism. The term halal tourism is the impact of many requests from Muslim world community, especially those from the Middle East, who want comfort in enjoying holiday packages at a tourist attraction that fits the framework of Islamic values. The results of a study by Masful (2017) confirmed that the implementation of halal tourism concept is more promoted on aspects of tourist attraction that are more polite and based on Islamic values in collaborating with the social-

Received: 2018-10-16, Revised 2018-10-16, Accepted: 2019-05-27

Print ISSN: 0215-8175; Online ISSN: 2303-2499. DOI: http://dx.doi.org/10.29313/mimbar.v35i1.4134

Accredited $\mathbf{S} 2$ based on the decree No.10/E/KPT/2019 until 2024. Indexed by DOAJ, Sinta, Garuda, Crossreff, Dimensions 
cultural identity of tourist locations. In the past few years, Indonesia has been invaded by foreign tourists, especially from Middle Eastern countries. This tourist visit originating from the Middle East is the result of delivering messages that offer many halal tourism concepts contained in a tourist attraction. The main prerequisites for halal tourism in a tourist attraction are the availability of worship facilities and culinary offering in accordance with the Islamic concept. The conditions in these tourist destinations indicate that since long ago Indonesia actually knew and applied the Islamic concept in tourism activities; the presentation of religious facilities and halal food was originally intended for local tourists. However, along with the development of tourism business, the concept that has already been implemented is now has the term of halal tourism or sharia tourism, which has made Indonesian tourism increasingly targeted by potential visitors and tourism investors from abroad, especially from the Middle East.

Based on statistical data from the Ministry of Tourism and BPS (Central Bureau of Statistics), foreign tourist arrivals in Indonesia can be seen in the Table 1.

It is different from the target age of tourist visits based on data from world survey institutions showing that world population growth has now reached 7.3 billion people spread across various parts of the world. Based on age, the development of Muslim population can be seen from the Table 2 .

Data in Table 2 show that in macroeconomic opportunities there are various economic sectors which can be used as market business targeting Muslim population. The economic sectors that can be developed based on Islamic values (sharia), to name a few, are financial business (banking \& insurance), food and beverage industry, media and entertainment industry, travel agents, pharmaceutical industry, clothing industry, and cosmetics. With a variety of businesses based on sharia values that are supported by the development of sophisticated information and communication technology or often called the industrial revolution 4.0, the young Muslim population is a very promising business target for businesses with a percentage of $23 \%$ of the Muslim population aged 15-29 years is estimated to be a young traveler. The presence of young tourists is inseparable from changes in the behavior of generation $Y$ (millennials) who always use mobile devices in their various activities, including in searching for tourist destinations. On the other hand, regarding lifestyle, young devout and modern Muslims are very adapted to the development of current world trends so that they become a very potential target in developing a tourism service business based on Islamic values. Thus, halal tourism is a new form of strategy in smooth and diplomatic relations with various countries (Subarkah, 2018).

The Indonesian tourism market has experienced a significant increase in tourist visits based on the two quantitative data above. As a country with the largest Muslim population in the world, Indonesia has a huge opportunity to develop the potential of

Table 1

Foreign Tourists Visit in 2014-2018

\begin{tabular}{llll}
\hline No & Year & Amount & Origin of Country \\
\hline 11 & 2014 & 9.435 .411 & Great China (Tiongkok, Taiwan, and Hongkong), Europe, \\
22 & 2015 & 10.406 .759 & England, French, Germany, Dutch, and Republik Checz), \\
33 & 2016 & 11.519 .275 & Singapore, Malaysia, Australia, Japan, India, South Korea, \\
44 & 2017 & 14.039 .799 & United States, and Middle East (Arab Saudi and Egypt) \\
55 & January-June 2018 & 6.166 .109 & \\
\hline
\end{tabular}

Source: Ministry of Tourism (2017)

Table 2

Number of Muslim Populations by Age

\begin{tabular}{clll}
\hline No. & \multicolumn{1}{c}{ Age } & $\begin{array}{c}\text { Percentage } \\
(\%)\end{array}$ & \multicolumn{1}{c}{ Amount (People) } \\
\hline 1 & Overall Worldwide Population & $24 \%$ & 1,75 Billion \\
2 & Populations under 15 years & $33 \%$ & 580 Million \\
3 & Population under 30 years old & $66 \%$ & 1,2 Billion \\
\hline
\end{tabular}

Source: (Shelina Janmohamed, 2018) 
a variety of tourism, especially the concept of halal tourism in each region. In order to achieve the development of halal tourism, efforts are needed by the government to create a tourism marketing communication strategy which is more detailed and implementable to communicate halal tourism to stakeholders and the community (Pratiwi, Dida, \& Sjafirah, 2018). At present, delivering the message of halal tourism in Indonesia is still limited to the "terms" that must be met in the implementation of tourism service industry with indicators of the availability of religious facilities, halal food, and services. If this halal tourism market trend wants to be improved, the government and the public should begin to manage things seriously in implementing halal tourism professionally. One professional form in organizing halal tourism is the existence of a clear and directed regulation that can be well implemented by the central government and the provincial /district/city government.

The trend of halal tourism concept can be an alternative for the foundation of a tourism implementation program that can withstand the economic shock caused by the financial and political crisis, with an estimate of 5 million foreign tourist visits to Indonesia. The magnitude of the potential of Indonesian halal tourism is manifested in the form of natural, cultural, and artificial tourism that can guarantee the development of the main destinations of world halal tourism to be promoted sustainably and professionally. On the other hand, the implementation of tourism activities is often associated with things that become obstacles in the development of regional tourism. This condition is in accordance with the statement from Haryani \& Huda (2018) stating that tourism management can result in an environmental quality decrease, lack of public facilities, and inadequate infrastructure of tourist destination objects. Thus, to get a better or even superior Indonesian tourism management, the government and community alike should seriously realize the concept of tourism, especially sharia or halalbased by building infrastructure, fostering tourism institutions, utilizing information technology, and strengthening the promotion of tourism destinations through marketing public relations (MPR) approaches which is done consistently.

As a part of national tourism, halal tourism can have a positive impact on the economic community development in an area. Regarding innovation and creativity in promoting halal tourism objects, the delivery of halal tourism information must be clear and understandable for tourists. The clarity and consistency of halal tourism message by the government towards the community is important as part of an effort to publish tourist information that can be targeted by tourists. Through marketing public relations approach to strengthen halal tourism activities, it will have a sufficient impact both in the delivery of ideas and promotion by the government and halal tourism industry entrepreneurs to the public through certain communication media.

The government which has the authority to regulate policies, including in tourism, has an interest in being able to develop a variety of Indonesian tourism that does not only rely on conventional tourism aspects. In the context of tourism variety formation, the government launched halal tourism policies in Indonesia in response to the growing level of growth and development of the world Islamic economy. A form of government's seriousness in the development of halal tourism is by establishing several provincial regions serve as pilot projects for the potential development of Indonesian halal tourism with ideal and highest achievement to be the best halal tourism destination in the world.

West Java was chosen as the potential region to develop halal tourism, and this become a challenge for tourism industry stakeholders to actualize it professionally. One area with a variety of tourism potential in West Java is Priangan region, namely Garut and Pangandaran where the level of tourist visits to these regions has always increased significantly. Garut is known as "Swiss van Java" and Pangandaran as "Hawaii in West Java", these two have become excellent attractions for most domestic and foreign tourists visiting West Java. Tourism potential that can be developed in Garut is natural and cultural conservation tourism, while in Pangandaran is community-based maritime tourism. The diverse potential of tourist destinations in the two regions has provided an opportunity for the government to be able to encourage the development of a variety of national tourism towards the implementation of halal tourism.

In implementing halal tourism in Garut and Pangandaran regions, tourism stakeholders face their own obstacles of, synchronizing the meaning and perception of halal tourism implementation among them. This was conveyed by $\mathrm{R}$ as the Chairman of 
Garut Travel Association (ITGA) who said that most tourism actors still perceive halal tourism as the implementation of tourism limited by Islamic rules that can "inflict a financial loss" in tourism activities that have been running so far which contains elements of pleasure and comfort for visitors. Whereas, DAW as the organizer of Tourism Activist Group (Kompepar) Pangandaran considers that halal tourism is less suitable for Pangandaran because the area is based on coastal tourism, which in fact will always be considered opposite to the concept of halal tourism. This statement is reinforced by the reality that there are still few or almost no tourism industry players in Garut and Pangandaran regions which formally implement halal tourist destination areas, both in terms of orderly visiting tourist attractions and specializing hotel/lodge names that conceptualize sharia or halal tourism.

Based on the background above, it would be very interesting if this study is conducted towards the government's efforts in preparing an area to be used as halal tourism, especially areas in Priangan region of Garut and Pangandaran through public relations approach. Public relations studies are very important as part of the main activities in an organization, namely supporting organizational policies so that they can be accepted by stakeholders through interesting and creative packaging messages. In relation to tourism, the function of public relations is very crucial in shaping public opinion to support the existence of organizations and also the government regarding a policy such as penetrating the concept of halal tourism to the regions. Penetration of halal tourism concept in public relations can be done using marketing public relations strategy. The marketing public relations strategy in halal tourism activities is a series of communication from halal tourism stakeholders to get targeted effectively and at the same time get destination brands from the public. This study was conducted in order to answer the problem formulation based on the above phenomenon, namely "how to use halal tourism marketing public relations strategy in Garut and Pangandaran regions?"

\section{Research Methodology}

The research method used in this study is qualitative. it is used as a procedure to solvie research problems by providing an overview of the state or object of research about a person, institution, society, etc others at this time based on existing or natural facts (Nawawi, 1998). Qualitative problems are in narrow spaces with low variations but have unlimited depth (Bungin, 2007). The type of research in this study is descriptive, which does not give priority to meaning but rather emphasized to analyze the surface of the data, taking into account a phenomenon that occurs.

The subjects of this study were purposely selected tourism industry players in West Java, particularly in Garut and Pangandaran district, which, namely PHRI Garut General Secretary, Chair of Garut Travel Association/ Owner of Jasa Karunia Tourism Transport Service (ITGA) Garut, Chair of Café and Restaurant Association (AKAR) Garut, Garut Regional Tourism Promotion Agency Officer, Chair of Kompepar Cipanas Garut, General Secretary of the Sharia Economic Community (MES) Garut, Chancellor of IPI Garut, ATTAP Pangandaran organization, Management of Kompepar Pangandaran, Pangandaran Water Sport Entrepreneur, Pangandaran Tourism and Culture Office, and PHRI Pangandaran. In this study, researchers conducted interviews and observations on tourist destinations, and also used literature and supporting documents regarding halal tourism practices in Indonesia, especially those in West Java region.

\section{Results and Discussion}

\section{Tourism General Overview in Garut Regency}

Garut, whose capital is Tarogong Kidul, is one of the destinations for leisure in West Java of. As a city of leisure, Garut has the potential of natural tourist attraction and many beautiful and enchanting tourist destinations. Some tourist attractions in Garut are quite diverse, including Cipanas hot spring tours, Bungbulang waterfall tours, Papandayan mountain tours, Santolo, Sayang Heulang beach tours, Dodol Picnic culinary tours, Situ Bagendit garden tours, Cangkuang Temple cultural tours, and craft shopping tours (sheep and cow skin products). Various tourism potentials in Garut can become the basis for the development of tourism industry sector that can support the improvement of the quality of national-class and communitybased tourist destinations.

Some aspects that support the development of Garut tourism destination are shown in the table 3. 
Based on data from table 3 , it can be stated that the potential of Garut tourism has fulfilled the pillars of the development of destinations and the tourism industry from the elements of attraction, amenities, accessibility, and ancillary. However, related to the discourse of organizing the development of Garut tourist destinations towards halal tourism, basically, it has been carried out by each tourism actor by fulfilling the basic elements of halal tour packages assessment, namely religious facilities and halal food. This was stated by $T$ as Chair of the Association of Cafes and Restaurants (AKAR) Garut that tourism objects in Garut, in general, are in accordance with Islamic values, namely the availability of facilities and infrastructure for praying such as mosques and prayer rooms; foods, and beverages free from alcohol, and the like. Meanwhile, according to BG, as the Head of the Tourism and Culture Office of Garut Regency, the development of tourism in Garut is conducted by developing the tourist destinations, strengthening the quality of facilities and infrastructure in prominent tourist objects, exploring and encouraging ecotourism potential, and training tourism business actors to make Garut tourism more famous. The development efforts of the tourism sector have had a good impact on the image of Garut as one of the economists, beautiful, charming, and quality tourist destinations. The development of tourism facilities and infrastructure in Garut Regency can be one of the basic assessment factors in the effort to develop a more professional tourism aspect. Related to the problem of developing halal tourist destinations, until now Garut Regency government has formally established a legal tourism zone which conceptually referred to halal tourism implementation according to the Global Muslim Travel Index (GMTI). This is similar to what was stated by the Chair of Kompepar Cipanas Garut, and T, the General Secretary of PHRI, who revealed the same core message, that is the implementation of halal tourism in Garut has been carried out only in the symbol nuances in the form of physical display emblazoned in a tourist attraction, such as the prayer place and prayer tools. While NH, Rector of IPI Garut, stated that halal tourism activities carried out were in the form symbolizing Islamic values in the tourist area, which did not touch aspects of Islamic preaching content as desired from halal tourism destinations that can guarantee comfort in traveling, either personally, family or group.

Based on the results of interviews and observations in the field, it showed that the discourse of organizing halal tourism in Garut district is still not well-developed, although

Table 3

Development Variable of Tourist Destinations

\begin{tabular}{|c|c|c|c|}
\hline No. & Category & Finding & Description \\
\hline 1. & $\begin{array}{l}\text { Attraction } \\
\text { (Attractiveness) }\end{array}$ & $\begin{array}{l}\text { Garut has natural, cultural and man- } \\
\text { made tourism objects scattered in } \\
\text { the Regency Tourism Strategic Area } \\
\text { (KSPK) in accordance with Garut } \\
\text { District Regulation No.3 of } 2013 \text { about } \\
\text { the Master Plan for Regional Tourism } \\
\text { Development for } 2013-2017\end{array}$ & $\begin{array}{l}\text { KSPK of Urban Garut } \\
\text { KSPK of Central Garut } \\
\text { KSPK of North Garut } \\
\text { KSPK of South Garut }\end{array}$ \\
\hline 2. & Amenities (Facilities) & $\begin{array}{l}\text { The availability of better facilities and } \\
\text { infrastructure to support the process of } \\
\text { organizing the tourism industry }\end{array}$ & $\begin{array}{l}\text { Hotels/Lodgings/Homestays, } \\
\text { travel agencies, cafes/restaurants, } \\
\text { and guides are available at each } \\
\text { KSPK }\end{array}$ \\
\hline 3. & $\begin{array}{l}\text { Accessibility } \\
\text { (Affordability) }\end{array}$ & $\begin{array}{l}\text { Easy access of information and } \\
\text { affordability to tourist sites by tourists }\end{array}$ & $\begin{array}{l}\text { Communication facilities } \\
\text { and connectivity of public } \\
\text { transportation modes in the form } \\
\text { of bus and public transportation, } \\
\text { motorcycle taxis, and delman, } \\
\text { which are available at each KSPK }\end{array}$ \\
\hline 4. & $\begin{array}{l}\text { Ancillary } \\
\text { (Institutional) }\end{array}$ & $\begin{array}{l}\text { Supporting elements of tourism } \\
\text { management consisting of institutions, } \\
\text { community empowerment, and } \\
\text { marketing }\end{array}$ & $\begin{array}{l}\text { There is a system that supports } \\
\text { tourism implementation by the } \\
\text { community and KSPK branding } \\
\text { efforts by the government } \\
\text { (Tourism and Culture Office) and } \\
\text { stakeholders }\end{array}$ \\
\hline
\end{tabular}


the majority of population in Garut district is Muslim. However, there are Garut tourism industry players who attempt to explore the readiness of tourist destinations development towards the first halal tourist destinations in Garut which pioneered in the late 2017, that is The Great Oko in Selaawi sub-district. The halal tourism elements in The Great Oko tourist destination are horseback riding and archery, clothes that covering body, and are not permitted to bring illicit food and drinks. Those are part of the implementation of Islamic rules and values contained in the Koran and Hadith. The concept of halal tourism itself is defined as tourism activities carried out under conditions and supported by destinations and facilities according to Islamic law. The elements of Islamic law include halal food and beverage, available and convenient places/ facilities for praying, as well as separation space/room of men and women. The principal meaning of halal tourism is related to adherence to the rules and guidelines of the concept of halal and Islamic sharia (El-Gohary, 2016). In addition, according to $T$, the General Secretary of PHRI Garut, halal tourism in a critical perspective could be said to be part of the country's effort to get more income from ordinary tourism sector by targeting tourists from Middle East.

Discussing the concept of halal tourism in Garut raises a problem in the development of tourism areas in Garut. Most tourism industry players are waiting for juridical clarity from the district government regarding guidelines for implementation and integrated and applicable halal tourism technical instructions. Meanwhile, the social capital of tourism objects in Garut is still involving the customs of Sundanese ancestors, so that tourism practices are developed based on the daily lives of local people in the form of traditional and cultural events routinely carried out annually such as Gebyar Pesona Budaya Garut (Exhibition of Garut Culture) as a routine event of Garut Regency government in commemoration of the anniversary of Garut Regency. This annual Garut event was inaugurated as part of 100 National Wonderful Events that can be used as a means to promote Garut tourism with the tagline "Amazing Garut". Gebyar Pesona Budaya Garut is a combination of tourism programs regional development exhibitions and the performance of leading traditional cultural arts in Garut. Combining traditional and contemporary cultural concepts in halal tourism promotion activity would bring a conflict of interest, since the implementation of halal tourism is usually related to the concept of da'wah based on Islamic values which is not accustomed for tourists who come to Garut.

\section{General Condition of Tourism in Pan- gandaran Regency}

Pangandaran is a beach or marine tourism area located on the south coast of West Java, which is a favorite destination for residents of West Java and its surroundings. Referring to the pattern of tourism development in Pangandaran district, they have started since the 1980 s until now, tourism development in Pangandaran district has undergone a very significant change. In developing tourist destinations, Pangandaran beach has become very advanced after becoming a New Autonomous Region (DOB) as a district separated administratively from its parent district of Ciamis. The tourism sector has been the priority of development in Pangandaran because it is a lifeline to support economic growth and welfare of the Pangandaran community. They can categorize the tourism destination areas in Pangandaran based on tourists desires: beach tourism, hill tourism, river tourism, cultural site tours, historical tourism sites, artificial tourism, and nature reserve tourism.

The tourism object sold in Pangandaran district is not only the coastal area, but also ecotourism around mountains which offering adventure river water tourism around Parigi and Cijulang areas, such as the Grand Canyon and Citumang. Related to the development of tourist destinations, they determine Pangandaran district to become a worldclass tourism area as implied in the vision and mission of the current Pangandaran district government. To achive that, they invite all tourism stakeholders to support the realization of Pangandaran district's vision and mission as mentioned in the 2017-2022 medium-term development plan (RPJM). Based on that, they prioritize the action plan regarding the concept of tourism in Pangandaran district by considering the capacity of tourism development in the coastal area (marine tourism).

Several aspects supporting the development of tourism in Pangandaran district are shown in the Table 4.

Table 4 shows that since the Pangandaran district has become a new 
Table 4

Development Variable of Tourist Destinations

\begin{tabular}{lll}
\hline No. Category & Findings & Explanation \\
\hline 1. $\begin{array}{l}\text { Attraction } \\
\text { (Attractiveness) }\end{array}$ & $\begin{array}{l}\text { Pangandaran has natural, cultural and } \\
\text { man-made attractions }\end{array}$ & $\begin{array}{l}\text { Pangandaran has the potential of } \\
\text { beautiful and diverse natural tourism, } \\
\text { ranging from beaches, mountains, and } \\
\end{array}$ \\
& $\begin{array}{l}\text { village tourism to human resources } \\
\text { which can also be an attraction to } \\
\text { attract investors and tourists }\end{array}$
\end{tabular}

2. Amenities (Facilities)
Good facilities and infrastructure are Hotels/Lodgings/Homestays, travel available to support the process of agencies, cafes/restaurants, and organizing the tourism industry, which guides which are centralized in is concentrated in the Pangandaran Pangandaran sub-district Beach area
3. Accessibility (Affordability)
Easy access of information and affordability to tourist sites
Public transportation and communication facilities in the form of public bus and minibus transportation with excellent road infrastructure, the existence of Nusawiru Airport, and an information center for tourists/visitors
4. Ancillary (Institutional)
Supporting elements of tourism There is a community of tourism management consisting of institutions, activists who are active in the village, community empowerment, and sub-district, and district levels marketing

Source: data is processed from various research sources, 2018.

autonomous region, the tourism sector has become a superior program for district development. This happened because before becoming a district, Pangandaran had always become a favorite tourist attraction in southern West Java. Seeing the enormous potential of tourism in Pangandaran, which is based on river and marine tourism, it has become the basis for the district government to develop Pangandaran marine tourism in the direction of halal tourism.

Based on the results of research in the field, it shows that practically there is no halal tourism in Pangandaran because most hotels are not yet self-proclaimed as sharia hotels/ inns. This is as expressed by DA, who work at the management of Pangandaran Tour and Travel Association (ATTAP), stating that the definition of standard concept of halal tourism socialized by the West Java provincial government has not been distributed evenly among tourism business actors in
Pangandaran, including the lodging/hotel services entrepreneurs. Therefore, practice and concepts of complete halal tourism objects cannot be implemented properly among the actors, activists, and drivers of tourism in Pangandaran. In addition, there is a statement from IS, who represents Pangandaran Tourism Entrepreneurs, saying that tourism in Pangandaran is a marine tourism, so that conceptually, the implementation of halal tourism in Pangandaran will get "resistance" from marine tourism businesses that carry tourism packages which are less "harmonious" with Islamic values because it still allows tourists to swim in tight clothes and mix of swimming areas for men and women. Meanwhile, according to the AS, who work at the management of the PHRI Pangandaran, revealed that hotels and inns in Pangandaran to date have not applied the concept of sharia hotels because it considered limiting the category of tourists who will stay. So far, tourists who come to Pangandaran do not 
mind about halal tourist destinations because what is important for tourists is satisfaction they get at tourist attractions with indicators of enjoyed by many people, comfortable, cheap, and affordable s. The concept of halal tourism is part of the tourism development method that upholds the culture and Islamic values without degrading the values of existing localities.

A concrete form of commitment of Pangandaran district government in developing tourism as the district's flagship development program is revitalizing Pangandaran tourist area by building centers of stalls for traders in Pangandaran beach, improving the quality of guides collaborating with the Association of Indonesian Guides in Pangandaran region, and organize tourist parks that support marine tourism in Pangandaran. This condition was stated by AK, who represented the Department of Tourism and Culture of Pangandaran district, saying that in order to realize the vision of Pangandaran to become a global tourism district, safe and comfortable residence based on religious norms, revitalization is needed in achieving the vision of the next five-years development goals (2015-2020).

\section{Public Relations Marketing Strategy for Halal Tourism}

Indonesia has a very large halal tourism potential because it has a variety of tourist objects convenient to visit. So far, most Indonesian Muslim tourists visit neighboring countries such as Malaysia, Singapore, Thailand, the Philippines, Vietnam, and Brunei Darussalam. Indonesia has ten halal tourism destinations which are used as pilot projects, which are Aceh, West Sumatra, Riau \& Riau Islands, Jakarta, West Java, Central Java, Yogyakarta, East Java, NTB and South Sulawesi. They deliberately create halal tourism as a concept to facilitate Muslim communities to conduct tourism activities safely and comfortably and become an additional service for tourism destination managers (Nirwandar, 2015). Halal tourism is a friendly tourism concept for Muslim families, especially those from Middle East, Malaysia, Singapore, and Brunei Darussalam. The development of halal tourism leads not only to religious values, but also to the lifestyle of travelers in today's Muslim tours who prefer practical and Instagramable things.

Through a halal tourism program, it will be easier for tourists and the tourism service industry to organize tour packages that will be offered freely to Muslim communities. Conceptually, the implementation of halal tourism does not result in any party being harmed, for example regarding halal food, where all people who are not Muslims can also eat according to their tastes with nothing threatening their health. The existence of halal tourism is also beneficial for people who are non-Muslim, in the sense that halal lifestyle does not mean constricting and forcing people to do the same as Muslims, but it is only an option for organizers of tourism services to attract foreign tourists, especially those from neighboring countries, such as Malaysia.

The existence of Indonesian halal tourism is now increasingly resonated with the international's arena Muslim market, along with the development of information and communication technology which widely spread various potentials of nature tourism and sharia-based culture posted by millennials. Based on the assessment of Global Muslim Travel Index (GMTI) in 2015, it was shown that Indonesia's halal tourism position had risen to fourth place after Malaysia, the United Arab Emirates, and Turkey. Based on data, Muslim tourist visits to tourist destinations in Islamic countries can be seen in table 5 .

Table 5 concludes that domestically,

Table 5

Foreign Tourist Visits in 2016

\begin{tabular}{cllll}
\hline No & \multicolumn{1}{c}{ Country } & \multicolumn{1}{c}{$\begin{array}{c}\text { Total Foreign } \\
\text { Tourist }\end{array}$} & $\begin{array}{c}\text { Total Muslim } \\
\text { Foreign Tourist }\end{array}$ & $\begin{array}{c}\text { \% Total Muslim } \\
\text { Foreign Tourist }\end{array}$ \\
\hline 1 & Singapura & 16.403 .595 & 4.152 .500 & $25 \%$ \\
2 & Malaysia & 26.545 .936 & 6.435 .763 & $24 \%$ \\
3 & Indonesia & 12.023 .971 & 2.416 .686 & $22 \%$ \\
4 & Turki & 25.352 .213 & 5.158 .944 & $20 \%$ \\
5 & Thailand & 32.588 .303 & 5.290 .297 & $16 \%$ \\
6 & Uni Emirat Arab & 14.837 .000 & - & - \\
\hline
\end{tabular}

Source: Handayani (2018) 
Muslim tourists who visit Indonesia show an increase trend from year to year. Based on data from Global Muslim Travel Index (GMTI), since 2015 Indonesia 's rank has risen to 1 (one), and the average growth of tourism and foreign tourists visiting Indonesia is $18 \%$ or around 2.4 million people from 2015 to 2017 (Kemenpar, 2017). Based on the data presented in the table regarding foreign tourist visits, especially the potential of halal tourism development, Indonesia can attract $12,023,971$ foreign tourists in 2016 which could be the country's main source of income. Besides the potential of nature and culture, another major factor in halal tourism sector in Indonesia is the number of Muslim populations as the largest one in the world, which means Indonesia can become the main "beacon" in the implementation and development of the world-class halal tourism. That statement is reinforced by Widagdyo (2015) who states that Indonesia should be a potential market niche in tourism given the huge of Muslim population, which can be realized by combining the concept of tourism and Islamic values as to increase and systematically strengthened business opportunities. Another thing that supports the development of halal tourist destinations in Indonesia is the openness of community life, high levels of religious tolerance, harmony among religious people, and the convenience while worshiping become social capitals in implementing Indonesian halal tourism packages.

The growing development of halal tourism service industry in the regions in the following years made Indonesian government won 12 awards at the 2016 World Halal Tourism Awards event, International Travel Week Abu Dhabi (ITW) represented by Lombok Region, Sumatra Province West, and the Province of Aceh Darussalam; and got rank 3 (three) in category of top 10 (ten) halal friendly holiday destinations in 2016. In 2019, Indonesia is awarded as the best halal destination in the world GMTI version with the main indicator of assessment of access, communication, environment, and service. These three shreds of evidence show that the development of halal tourism in Indonesia is carried out seriously because it is very promising for the economic improvement of the community with the main goal to be the world Muslim community.

The tourism sector is a strategic sector for regional income. In order to get greater opportunities, tourism is developed in the form of support, regulations, and programs. Regulatory, the discourse of developing halal tourist destinations can have positive and negative social impacts for people around tourist destinations. The acceptability of halal tourism concept is still debatable in the circle of tourism stakeholders. Apart from these problems, the concept of halal tourism that has been proclaimed by the Ministry of Tourism since 2015 must be realized. The fact that there are number of local government bureaucrats who still disagree with the implementation of halal tourism in the ideal area can be an inhibiting factor for the realization of regional readiness to become a professional halal tourism object. The lack of understanding of the halal tourism concept that occurs among stakeholders can be bridged through the application of communication strategies in the form of marketing public relations. According to Harris (1993) as the initiator of Marketing Public Relations, "Marketing Public Relations (MPR) is the process of planning and evaluating programs that encourage purchase and customer through information on impressions that identify companies and their products with the needs concerns of customers ". Another definition that clarifies the MPR concept is from Thomas L. Harris who states that Public Relations Marketing is a strategy and implementation that integrates the concept of public relations with marketing in order to optimize organizational achievements to get good relationships with stakeholders (Kartikanwangi, Sarinastiti, \& Nugroho, 2013). In some cases, the MPR has the advantage of being able to persuasively influence and educate the public about a product or service or idea. Thus, the use of MPR in preparing the development of halal tourism destinations in the region need to be carried out in a strategic and sustainable manner by the central, provincial, district, and city governments. Furthermore, concerning the implementation of activities in MPR related to halal tourism, the public relations communication program can be used as a tool to realize the MPR strategy which consists of pulling (persuading/attracting public attention), pushing (stimulating/encouraging the public), and pass (influencing and creating public opinion ) tourism programs in order to form a means of discussion as well as a model for the development of halal tourism destinations in the region (Chatamallah, 2008). Efforts to develop halal tourism destinations in an area are not only implementing religious values in travel but 
also related to the growth and development of other tourism business industry sectors.

If Garut regency wants to succeed in halal tourism, the regional government needs to implement a massive, structured, and sustainable MPR strategy related to the development of halal tourism destinations. Although the legal and infrastructure regulations of Garut district are not that perfect for halal tourism, research data shows that the government has already informed to prepare Garut region to become one of the halal tourism development destinations. As proof, there are new tourist destinations in Selaawi subdistrict that have pioneered the concept of halal tourism. Regarding the implementation of halal tourism in Garut, $\mathrm{T}$, Chair of the café and Restaurant Association (AKAR), stated that:

\begin{abstract}
"... The concept of halal tourism has been informed by the government, but the more detail information about the mechanism of implementing halal tourism in Garut is not that clear ...".
\end{abstract}

From the results of the interview, it can be seen that basically the central government has delegated the provision of information to the provincial government, and Garut district has provided information on general tourism development plans that will be adjusted towards halal tourist destinations in the strategic tourism area of Garut. Therefore, for halal tourism discourse in Garut to be unanimously accepted by various stakeholders, a strategy is needed to foster awareness in the community through a marketing public relations approach. The marketing public relations strategy focuses on the government's efforts to encourage people to know and understand the halal tourism concepts and policies through information dissemination in collaboration with the tourism industry, the media, and tourism activist community, especially in the Cipanas Garut area.

Regarding the marketing public relations strategy carried out by Garut district government in preparing halal tourist destinations is to prioritize the push strategy approach. It aims to encourage an institution to expand its influence and marketing field regarding a product or idea that needs to be delivered to its target audience (Saputra \& Nasrullah, 2011). This push strategy was chosen to develop Garut's halal tourist destinations because it was largely supported by Garut District Regulation No.3 of 2013 concerning the Master Plan for Regional Tourism Development. This juridical aspect has at least given a point of enlightenment as the initial guideline reference for a tourism area that has the potential to be developed towards halal tourism packages that are friendly and satisfying the tourists. Information about halal tourism to certain circles in Garut is part of the push strategy carried out by the district government besides tourism promotion events in the wider community such as the Pesona Budaya Garut.

In Pangandaran region, the MPR strategy regarding tourism destinations is carried out by reporting various events through local mass media, the internet, and social media by tourism stakeholders such as the Pangandaran tourism activist group. The events included Pesta Laut (Sea Party) as a form of fishermen gratitude to God over what they have obtained, Festival Layang-Layang (Kite Festival), Pangandaran Triathlon Championship, Gebyar Tahun Baruan Pangandaran (New Year's Eve Party), etc which were held both by the district government and communities outside Pangandaran. The amount of information in the form of news in local mass media, internet, and social media show that tourism activists in the villages are very active in promoting tourism objects other than Pangandaran beach tourism. The spread of tourist information shows that MPR strategy that has been carried out is more on the pull and pass. They can identify this from the statement of the figure of Kompepar Pangandaran, TS, who states that:

\begin{abstract}
"... each village in Pangandaran has a group of tourism activists who function as managers of Pangandaran's new tourist attraction and as disseminators of information about attractions that are attractive and creative for domestic and foreign tourists to be noticed and visit.
\end{abstract}

The MPR pull strategy that occurs in Pangandaran can be seen from the many new tourist objects visited by tourists who come to Pangandaran in cooperation with the village government, the Tourism and Culture Office of Pangandaran district, Kompepar with tourism travel agents to promote and simultaneously become endorser and tour guide in the new Pangandaran tourist attraction. A large amount of Pangandaran tourism information indicates that there is a strong desire from the community to advance each region that has new tourism objects to be known and visited by tourists. Another thing related to 
the tourist attraction in Pangandaran was delivered by $\mathrm{A}$, a Head of Tourism and Culture Office of Pangandaran Regency, who stated that:

\begin{abstract}
"... there are 23 new tourist destinations in Pangandaran Regency, 5 of Pangandaran's main tourist attractions are managed directly by the district government, namely Pangandaran Beach, Krapyak Beach, Batu Hiu Beach, Grand Canyon, and Batu Karas Beach. While new tourism objects are still managed by each Kompepar and village government ..."
\end{abstract}

The pass strategy of MPR would be effective if the person who does it is a wellknown figure or institution that can give birth to a positive opinion on the object being preached or viral in the community. This is reinforced by Saputra \& Nasrullah, (2011) who explained that the passing strategy is an effort to create a public image that is generated through various activities and participation in community activities and cares about the social conditions occur. The practice of pass strategies in developing Pangandaran tourism uses more central figures of government, namely the Regent and Deputy Regent who endorses every national tourism activity in Pangandaran.

Related to the discourse on the development of halal destinations in Pangandaran, the strategy of MPR can refer to the pattern of Pangandaran marine tourism promotion activities so far to the wider community that are often carried it out. The term "halal" in tourism can become a major obstacle for the government to develop the Pangandaran region into a halal tourist area of Pangandaran tourism industry business groups because of the limited interpreting of what good halal tourism concept is in Table 6.

\section{Table 6 \\ Halal Marketing Public Relations (MPR) in Priangan}

\begin{tabular}{|c|c|}
\hline MPR Stages & Explanation \\
\hline Marketing & $\begin{array}{l}\text { Efforts to prepare halal } \\
\text { tourist destinations in the } \\
\text { area }\end{array}$ \\
\hline Marketing & Increasing regional \\
\hline Strategy & $\begin{array}{l}\text { readiness to become a } \\
\text { good and professional } \\
\text { halal tourist destination }\end{array}$ \\
\hline $\begin{array}{l}\text { Public Relations } \\
\text { Objective }\end{array}$ & $\begin{array}{l}\text { Persuade stakeholders } \\
\text { in the tourism sector } \\
\text { to realize tourism } \\
\text { diversification, namely } \\
\text { halal tourism programs }\end{array}$ \\
\hline
\end{tabular}

\begin{tabular}{ll}
$\begin{array}{l}\text { Public Relations } \\
\text { Strategy }\end{array}$ & $\begin{array}{l}\text { Communicate the } \\
\text { benefits and uses of } \\
\text { halal tourism through } \\
\text { regulation, event } \\
\text { promotion, reporting, and } \\
\text { raising public opinion }\end{array}$ \\
Work Program of & $\begin{array}{l}\text { Publications on Outdoor } \\
\text { Public Relations }\end{array}$ \\
& $\begin{array}{l}\text { Media, Digital Public } \\
\text { Relations, Media } \\
\text { Relations, Community } \\
\text { Relations, Government } \\
\text { Relations, Investor } \\
\text { Relations }\end{array}$ \\
\hline
\end{tabular}

Source: Results of Research Data, 2018

Due to the orientation of halal tourism that has led to industrialization, the perspective of public relations studies requires an effort to communicate in more structured ways as a business opportunity that is very tempting for anyone to get a positive assessment from various circles of society. Efforts to communicate about halal tourism can be done with marketing public relations, which usually the government institutions prioritize the term tourism promotion or integrated marketing communication. Tourism promotions associated with tourism development are carried out through brand recognition that uses a network of information found on social media such as Path, Facebook, YouTube, Instagram, and Twitter. In addition, it was found that advertisements, promotions, and messages on social media delivered from person to person had a positive relationship with the development of tourism destinations. However, there are times when interactive marketing on social media has an insignificant role in an activity because of factors outside human power such as disasters and human error (Adetunji \& Ishak, 2018).

The role of the government in developing halal tourism destinations has become very important in an effort to encourage the pace of economic growth in the community. In addition, regular relationships and good communication with investors, travel operators, entrepreneurs, and tourism conscious groups in the community will have an impact on the development of a better tourism business. While related to the millennium era, the development of halal tourism can be done by embracing all online and offline communities to promote and Public Relations that Indonesian tourism must be preserved for the welfare of the nation. Efforts to involve cyberspace communities in the development of halal tourist destinations, 
in line with what was examined by (Nurhadi, 2017) regarding social interactions occur in new media will produce effective messages as a formulation of message exchanges, generating similar interests in an issue, and giving new thought in the discussion room both privately and publicly through group. The outcome of social interaction in new media is positioning the issue of tourism that will become a trending topic as the results of posts on all social media accounts, whether in the form of photos, videos, infographics, slide shows, updating status, or chat. However, the advantages of online media as a new medium that should help facilitate management work in the field of communication to manage communication with public still cannot be optimized, including in terms of developing halal tourism (Yazid, 2015).

Theoretically, the development of halal tourism sector in Indonesia can be

Table 7

Programs Featured Halal Tourism Development in Indonesia

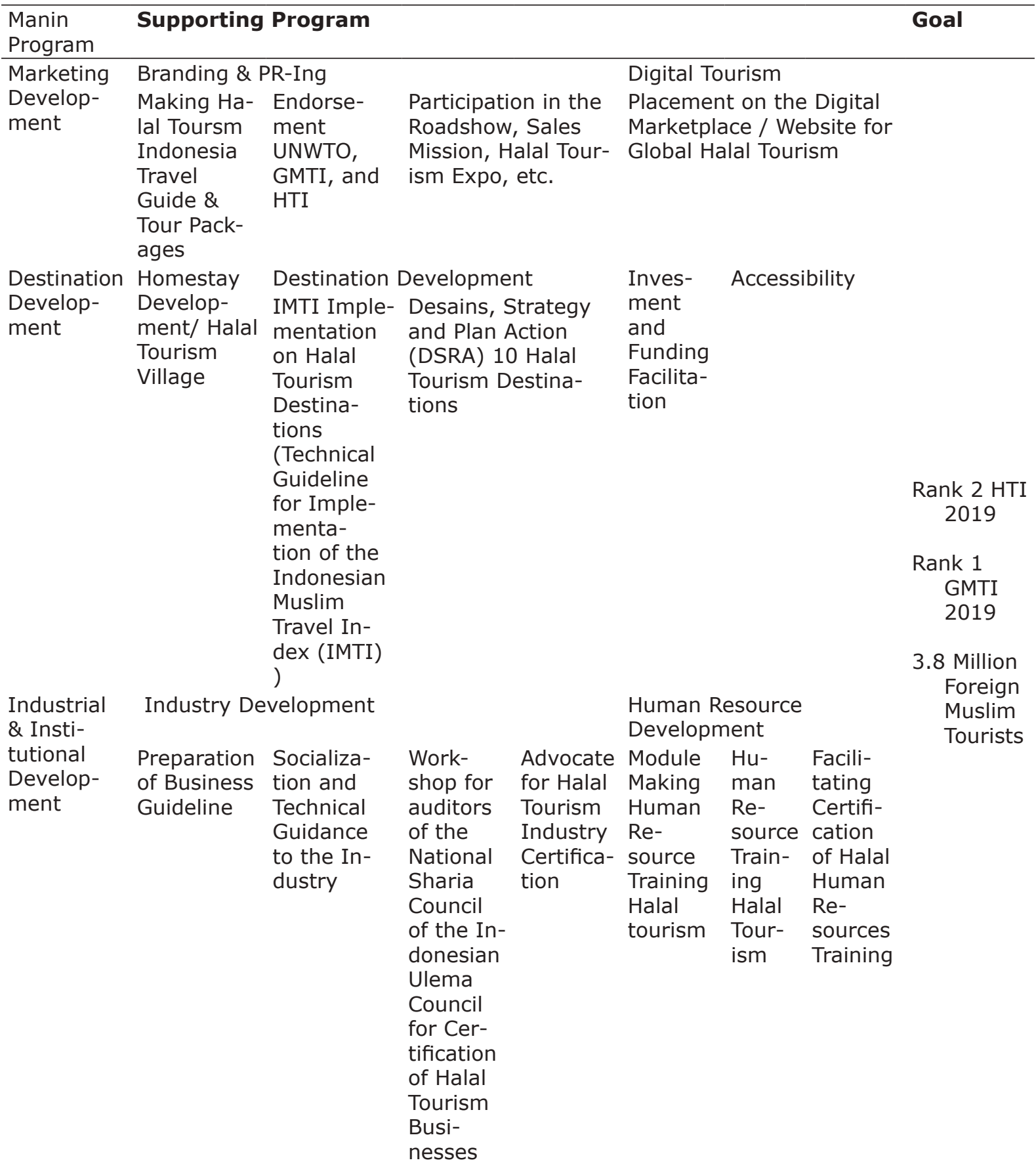


done by some marketing public relations strategies. First, the strategy of pulling (persuading) is the effort to communicate messages that are of public interest to be involved in the tourism activities offered. The pull strategy in halal tourism is done by offering the advantages of facilities that are physically and psychologically comfortable as well as travel experiences for potential tourists to visit tourist sites by making tourist destinations, profile tourist destinations, tourist gift packages, advertisements, and social campaigns using mass media and social media on tourist destinations that are delivered to travel agents and the public. Second, the push (stimulating) strategy is an effort to deliver messages which can stimulate the public to be involved in halal tourism activities through activities of natural and cultural tourism, institutional development, mentoring and training to improve human resource capacity for halal tourism villages by the government, tourism people, mass media people, and tourism activists. Pampering prospective tourists by involving them in an experimental activation is actually an effort to attract the interest of prospective tourists themselves. Third, the pass strategy (influence), the existence of collaborative efforts and equal interaction between tourism service industry players in developing halal tourism destinations through collaborative programs with third parties as influencers, such as journalists, ambassadors, key opinion leaders, and endorser of excellent services of a tourist destination halal in Indonesia in order to create a favorable public opinion among tourists. Institutionally, the government has high power to carry out collaborative practices in tourism on a bilateral, multilateral, and regional basis to develop a more advanced and professional halal tourism. The strength of cooperation in a moment of promotion of halal tourism can encourage the creation of conversations that influence the community to choose tourist destinations that are in accordance with the interests and ethics of a Muslim. Commodities in the digital era has resulted in the emergence of communication activities such as buzzing, social media users' mobilization, and social media monitoring (Saraswati, 2018).

In an effort to prepare halal tourist destination areas in Indonesia to be realized soon, the government represented by the Ministry of Tourism developed a halal tourism development strategy which can be seen in the table 7.
From Table 7, it can be explained that the main program of halal tourism development consists of marketing development, destination development, and industrial \& institutional development. Through the three flagship program schemes on halal tourism development carried out by the Ministry of Tourism, marketing public relations strategy carry out its role of helping halal tourism service industry players to develop public awareness about tourist destinations related to products and services launched (Sari \& Widayatmoko, 2011). Marketing Public Relations is the next development of the Mega Marketing concept which was popularized by Thomas L. Haris in 1991, by viewing Public Relations work practices in marketing activities. Marketing public relations is a process of planning and evaluating communication programs that stimulate interest, knowledge, awareness, and behavior in the form of satisfaction of prospective customers through packaged impressions and associated with the identity of an organization/institution and its products/services according to the needs, desires, attention, and interests of the target audience. Therefore, the MPR is the concept of public relations which is relatively relevant for marketing activities to help the organizations achieve their marketing goals (Suparmo, 2011).

Finally, communication delivered through MPR strategy is a form of the ongoing conversation on the basis of the same perception and meaning of a message to be conveyed to the public regarding issue of halal tourism. That the most important factor in tourism marketing is an increase in participation from local governments, diversifying products, and improving the quality of tourism services (Made, Widiastini, \& Andiani, 2012). The three tourism marketing factors are important to develop the regions in Indonesia to become the world-class halal tourist destinations. In addition to the three important factors in organizing halal tourism according to Eri Mariwijaya, SE, MBA as Executive Director of YPM Salman, ITB, is that halal tourism will develop well if it is equipped with Halal Inspection from institutions that provide halal certification, the concept of halal tourism, and regional regulations strengthen the legitimacy of the implementation of halal tourism for the community as a guarantee of legal certainty for halal tourism .

Thus, the reason for the development of halal tourism in Indonesia to be immediately 
implemented because basically, Indonesia has already had the philosophical and sociographic tools, namely as the largest Muslim country in the world with natural, cultural, and artificial tourism potential which is spread in every island. More specifically, what is meant by a philosophical foundation in the development of halal tourism in Indonesia is the development of the economy in order to support the acceleration of community welfare, equal opportunity for business, to get benefit, and be able to face the challenges of life while paying attention to the prevailing cultural values in society with the basic values of the state that provide flexibility for tourists in carrying out their worship activities in a destination location. While the sociological foundation is the birth of Regional Regulations (Perda) concerning halal tourism as a juridical aspect for ensuring the implementation of halal tourism which intersects with social life of the community without having any different with the hereditary or religious side as the main factor of halal tourism that can be well developed (Jaelani : 2018). How important is the development of halal tourism destinations in the area, especially in the Priangan region? According to Yoharman Syamsu A.Md.Par., S. Sos., M.Sc as a tourism practitioner who works at the Bandung District Tourism Office, saying that there must be the synergy between stakeholders for tourism businesses, the government, the media, academics, and the community to work hand in hand to make Indonesia a classy, modern, and unique halal world tourist area in persuading domestic and foreign tourists.

\section{Conclusions}

The synergy between marketing and public relations in the development of halal tourism destinations can create and strengthen the brand of halal tourist destinations that have a good image and reputation among tourists. The creation of the image and reputation of halal tourist destinations is inseparable from the marketing public relations strategy in the form of pull, push. and pass that is carried out structurally by the government and tourism industry players. In a pull strategy, halal tourism promotion is packaged in special or annual events organized by the government and the tourism activist community in the area. In push strategy, the government organizes educational programs, disseminates information and halal tourism policies to the provincial, district and city levels; and in the passing strategy, the development of halal tourism is carried out by establishing cooperation between local governments and various elements of tourism stakeholder groups to become endorsers of tourism activities.

\section{References}

Adetunji, R. R., \& Ishak, M. S. (2018). Social Media Marketing Communication and Consumer-Based Brand Equity : An Account of Automotive Brands in Malaysia. Malaysian Journal of Communication, 34(1), 1-19.

Bungin, B. (2007). Penelitian Kualitatif: Komunikasi, Ekonomi, Kebijakan Publik, dan Ilmu Sosial Lainnya. Jakarta: PT. Kencana Prenada Media Group.

Chatamallah, M. (2008). Strategi "Public Relations" dalam Promosi Pariwisata: Studi Kasus dengan Pendekatan "Marketing Public Relations" di Provinsi Banten. MediaTor (Jurnal Komunikasi), 9(2), 393-402. Retrieved from http://ejournal. unisba.ac.id/index.php/mediator/article/ view/ 1120

El-Gohary, H. (2016). Halal tourism, is it really Halal? Tourism Management Perspectives, 19, 124-130. https://doi.org/10.1016/j. tmp.2015.12.013

Handayani, R. (2018). Pariwisata Halal Di Era Milineal. Bandung.

Harris, T. L. (1993). The Marketers Guide to Public Relations: How Todays Companies are Using the New PR Gain a Competitive Edge. New York: John Willey and Son, Inc.

Haryani, \& Huda, N. (2018). Developing Fishing Tourism Destination Based on " Anak Nagari " Concept in Padang City. Mimbar : Jurnal Sosial Dan Pembangunan, 34(1), 51-60.

Jaelani, A. K. (2018). Pengembangan Destinasi Pariwisata Halal Pada Era Otonomi Luas di Provinsi Nusa Tenggara Barat. Pariwisata, 5(1), 56-67.

Kartikanwangi, D., Sarinastiti, N., \& Nugroho, A. (2013). Evaluasi Strategi dan Implementasi 360 Communications di Indonesia. Jurnal Interact, 2(1), 18-31.

Made, N., Widiastini, A., \& Andiani, N. D. (2012). Strategi Pemasaran Pariwisata Di Kabupaten Buleleng, Bali. Jurnal Ilmu Sosial Dan Humaniora, 1(1), 1-19.

Masful, M. F. (2017). Pariwisata Syariah: Suatu Konsep Kepercayaan dan Nilai Budaya Lokal di Daerah Pedalaman Pilubang, Payakumbuh, Sumatera Barat. 
Jurnal The Messengger, 9(1), 1-8.

Nawawi, H. (1998). Metode Penelitian Bidang Sosial. Yogyakarta: Universitas Gadjah Mada Press.

Nirwandar, S. (2015). Dimensi Luas Itu Bernama Pariwisata. Pesona Magazine, 3-8.

Nurhadi, Z. F. (2017). Model Komunikasi Sosial remaja Melalui Media Twitter. Jurnal ASPIKOM, 3(3), 539-549.

Pratiwi, S. R., Dida, S., \& Sjafirah, N. A. (2018). Strategi komunikasi dalam membangun awareness wisata halal di kota Bandung. Jurnal Kajian Komunikasi, 6(1), 78-90.

Saputra, W., \& Nasrullah, R. (2011). Public Relations 2.0: Teori dan Praktik Public Relations di Era Cyber. Depok: Gramata Publishing.

Saraswati, M. S. (2018). Social Media and the Political Campaign Industry in Indonesia. Jurnal Komunikasi ISKI, 03(01), 51-65.

Sari, F. S., \& Widayatmoko. (2011). Pengaruh
Marketing Public Relations terhadap Penciptaan Citra Merek Cafe Gran Via. Jurnal Komunikasi, III (2), 50-58.

Shelina Janmohamed. (2018). From Hijabs To High Fashion. Retrieved from https:// ogilvy.co.uk/news/hijabs-high-fashion

Subarkah, A. R. (2018). Diplomasi Pariwisata Halal Nusa Tenggara Barat. Intermestic: Journal of International Studies, 2(2), 188-203. https://doi.org/10.24198/ intermestic.v2n2.6

Suparmo, L. (2011). Aspek IImu Komunikasi dalam Public Relations. Jakarta: PT. Indeks.

Widyastuti, D. A. R. (2011). Komodifikasi Upacara Religi Dalam Pemasaran Pariwisata. Jurnal Komunikasi, 1(2), 197208. Retrieved from http://jurnal.aspikom. org/wp-content/uploads/2015/02/jka-vol1-no-2-jan-2011-widyastuti.pdf

Yazid, T. P. (2015). Implementasi Cyber Public Relations Melalui Pengelolaan Website Pemerintah. Jurnal IImu Komunikasi, 6(2), 160-173. 